\section{KRIYA TRADISIONAL DALAM PERSPEKTIF HKI}

\section{Nyoman Lodra}

Pendidikan Seni Rupa dan Kerajinan Universitas Negeri Surabaya

\section{Abstrak}

Kriya Tradisional dimaksudkan adalah karya dibuat dengan keterampilan tangan yang diperuntukan sebagai "media religi" seperti Arca, Patung, Rajah, Anyam dan Artefak lainnya. Media religi dibuat dari batu, kayu, kain, tepung, daging dan sejenisnya oleh kelompok suku tertentu difungsikan sebagai perentara permohonan yang sifatnya trasidensi. Oleh Gerlach \& Ely Media diartikan sebagai medium yang fungsinya untuk perantara atau pengantar (dalam Azhar Arsyad, 2009, 3). Religi dimaksudkan sebagai peradaban manusia terikat pada keyakinan, terungkap dalam bentuk upacara ritual yang bersifat animisme dan monotheisme. Para kreator seni media religi tersebut dijadikan objek kreasi kretif dan menghasilkan produk seni, seperti seni Tari, Tabuh, Rupa, Kerajinan dan Kriya tradisional. Dalam perkembangan pasar global, Kriya Tradisional yang diwujudkan dengan kemampuan intelektual dikelompokan sebagai jenis karya "foklor". Pada sisi yang lain karya "foklor" di klaim secara indivual atau kelompok sebagai Hak Cipta dalam Undang-Undang Hak Kekayaan Intelektual (HKI). Hak Kekayaan Intelektual (HKI) adalah hak atas kepemilikan kebendaan dan karyakarya yang timbul atau lahir karena kemampuan intelektualitas manusia (Simorangkir JCT, 2008: 11)

Kata kunci: media, religi, HKI, budaya global

\section{KRIYA TRADISIONAL DALAM PERSPEKTIF HKI}

\section{Abstract}

What is meant by kriya tradisional is artistic works such as statues, sculptures, tattoos, and other artefacts, which are used as a kind of sacred media for religious ceremony. These works of art are made of stones, wood, cloth, flour, meat, etc. by certain ethnic groups and function as a transcedental mediator used to make wishes. Gerlach \& Ely define media as a medium which functions as a mediator (in Azhar Arsyad, 2009, 3), while the term "sacred" means human civilization related to people's beliefs revealed in ritual ceremonies reflecting animism and monotheism. By producing many artistic works such as dance, traditional music, fine arts, crafts, and many other works, the artists can see these sacred media as parts of their creative products. In this globalization era kriya tradisional produced by using intellectual ability are categorized into folklore, which can be claimed as individual or group works' intellectual property rights, a legal justification to claim that a certain product resulting from intellectual ability belongs to its creator (Simorangkir JCT, 2008: 11)

Keywords: media, sacred, intellectual property rights, global culture

\section{PENDAHULUAN}

Kriya tradisional dimaksudkan sebagai karya yang dihasikan dari keterampilan tangan berupa benda perwujudan yang bersifat simbolis. Benda perwujudan dibuat dengan dasar pertimbangan pada kepercayaan dan keyakinan bersifat animisme dan monoteisme. Benda perwujudan tersebut diperistiwakan dalam rangkaian kegiatan religi. Religi diartikan sebagai aktivitas manusia dalam bentuk pengorbanan suci, material, dan non material dengan dasar adanya kepercayaan dan keyakinan pada kekuatan "roh" yang mampu mengatasi persoalan hidup manusia. Kriya tradisional tersebut oleh Lodra (2013), disebut sebagai "media religi," seperti arca, patung, anyam, dan artefak. "Media religi" ditandai dengan sifat-sifat yang khusus dan menimbulkan rasa hormat (Sumandiyono, 2006: 31).

Religi atau ritual religi terus berkembang sejalan dengan pengalaman hidup manusia lahir maupun batin. Media religi tidak lagi sebatas benda simbolis yang semata-mata sebagai perantara "doa-doa" atau permohonan untuk perlindungan, kesejahteraan, keselamatan, tetapi telah merambah pada sentuhan nilai estetis (keindahan). Prosesi religi atau disebut sebagai ritus ritual keagamaan berjalan secara bersiklus, dan berulang-ulang. Dalam pengulangan ritus ritual, kriya tradisional (media religi) bersifat simbolis terus mengalami penyempurnaan dan kemudian menjadi cikal bakal berkesenian.

Kriya tradisional atau disebut sebagai media religi yang bersifat sakral tersebut terus berkembang secara variatif, ornamentik bersamaan dengan makin mendalamnya "srada" dan "bhakti" dalam pengorbanan suci. Kriya tradisional berevolusi menjadi benda-benda kesenian untuk kepentingan keindahan (estetik) dan pencitraan bersamaan masuknya pengaruh global. Oleh Appadurai (Ritzer dan Douglas, 2007: 598), globalisasi terkait dengan penggerakan manusia (ethnoscape), pergerakan media (mediascape), pergerakan teknologi (technoscape), pergerakan uang (finanscape), dan pergerakan ideologi (ideoscape). Dalam konteks di atas, Anthony Giddens melihat bentuk globalisasi yang sekarang sebagai intensifikasi, jejaringan relasi-relasi sosial di seluruh dunia yang mempertautkan lokalitas-lokalitas, seperti kriya tradisional. Makin menguatnya pengaruh global bentuk perwujudan kriya tradisional atau media religi makin sempurna dan beragamnya. 


\section{KARAKTERISTIK KRIYA TRADISIONAL}

Pada masa peradaban Hindu, media digunakan dalam ritus ritual yang bernafaskan religi untuk difungsikan (lahir-batin) bagi pencapaian "jagadhita" dan pencitraan. Sedangkan kegiatan ritual religi muncul karena adanya kegelisahan, keresahan, ketakutan, dan keyakinan pada kekuatan di luar dir manusia yang mampu mengatasi segala persoalannya (Irwan Abdulah: 2009).

Kriya tradisional atau media religi dikelompokan menurut bahan, bentuk, dan fungsi. Berdasarkan bahan pembentuknya, media religi ada yang dibuat dari kayu, kain, kertas, daun, batu, emas, besi, perak, perunggu, dan sejenisnya dengan teknik pahat, picing, tempel, gambar. Berdasarkan bentuknya, kriya tradisional dimanfaatkan sebagai perwujudan dewa-dewi, roh, manusia, binatang dengan gaya dekoratif, klasik dengan metode penciptaan, imajinatif, dan storsi Berdasarkan fungsinya, kriya tradisional digunakan sebagai perantara doa "permohonan" dengan segala manifestasi kebesaran dan kekuasaan beliau. Doa permohonan tersebut dikontekstualkan dengan kata "seni" yang berasal dari kata sani yang berarti pemujaan, persembahan, pelayanan, dan permintaan. Ha tersebut ditegaskan bahwa keindahan kriya tradisional yang difungsikan sebagai "media religi" tidak terlepas dari kata seni dalam kegiatan ritual. Sementara itu, doa pemujaan yang dimaksudkan tersebut sudah ada sejak zaman prasejarah dan Bali Kuno (Ardana, 2007:.11-17). Richard Falk (2008: 36) menyebutnya sebagai kreativitas spiritual.

Kriya tradisional merupakan warisan budaya yang dikelompokkan ke dalam "foklor," seperti jenis ragam hias, bentuk pahatan, ukiran, patung, bangunan candi, pura, (tangible) dan konsep filosofi spiritualnya (itangible) bersifat sakral, menjadikan sumber kreasi kreatif yang kemudian berkembang menjadi kesenian yang sekuler. Oleh praktisi dan pengamat seni, "media religi", dipahami sebagai cikal-bakal kesenian klasik dan tradisional. Kriya tradisional sebagai wujud benda seni yang mengandung pengalaman spiritual yang menjadi benda berharga, terhormat, dan bersifat sakral. Oleh Dibia (2013), seni sakral memiliki "power" (kekuatan) untuk penyatuan sekaligus penghancuran tergantung pada arah pemanfaatannya.

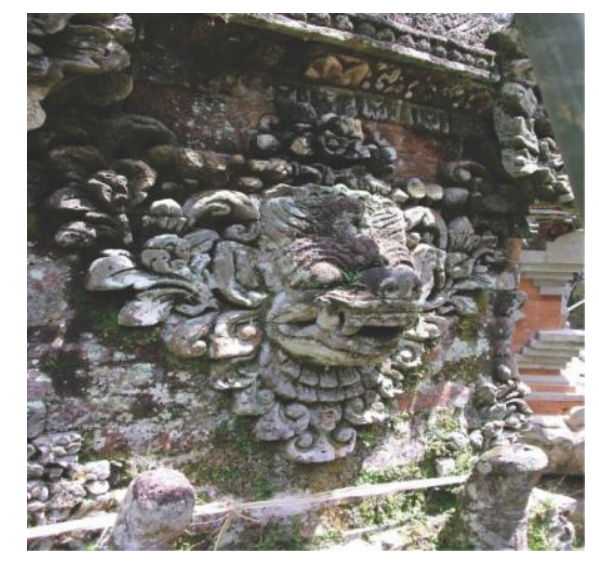

Gambar 1. Motif Ornamen.

Tradisional atau "Media Religi."

Sumber Gambar: Lodra, 2012.

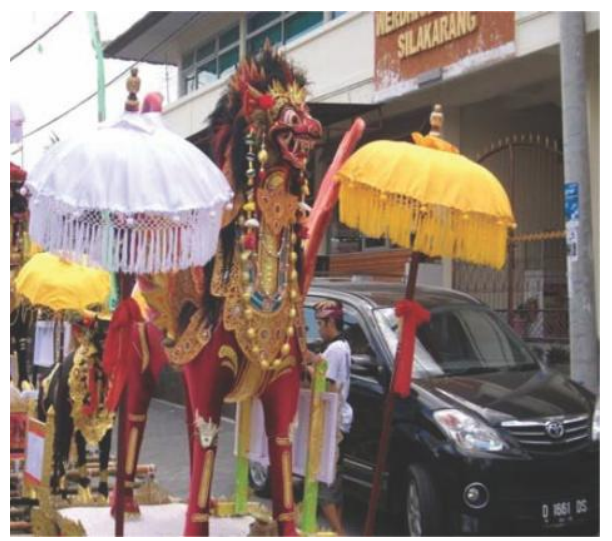

Gambar 2. Petulangan Lembu Kriya Kriya Tradisional atau "Media Religi," Sumber Gambar: Lodra, 2012.
Kedua gambar kriya tradisional atau media religi tersebut di atas dihormati dan disakralkan, oleh Hoggart dan Raymond Williams (dalam Chris Barker, 2008: 16) hal tersebut sesuai dengan konsep kulturalisme, suatu kelaziman kebudayaan, aspek kreatif, mengkontruksi praktik bermakna bersama dalam tradisi kultural.

Bersamaan dengan muncul budaya industri kreatif, dengan landasan agama, adat, dan budaya, kriya tradisional yang bersifat sakral berkembang dan berubah menjadi budaya populer, diproduksi untuk kepentingan estetik, pencitraan dan komersial. Menurut Farley (dalam Piotr Sztompka, 2007: 5) perubahan sosial tersebut merupakan perubahan pola perilaku, hubungan sosial, lembaga, dan struktur sosial pada waktu tertentu. Hal yang sama dikatakan Hoovelt (Sojogyo, 1990: 60) perubahan akan tetap berubah selama masyarakat sosial melakukan interaksi dengan lingkungannya. Menurut Gidden (Piotr Sztomka, 2007, 82) perubahan yang dimaksud merupakan sebuah mode atau gaya hidup masyarakat menuju kehidupan modernitas. Apapun bentuk perubahan yang dimaksudkan tersebut membuat masyarakat pendukung merasakan kegelisahan, konflik, dan kegoncangan sosial. Colin Hines (dalam Smiers, 2009: 21) menggambarkan sebagai intensitas yang senantiasa makin meningkat dari integrasi perekonomian nasional ke ekonomi global melalui peraturan investasi dan perdagangan, dibantu kecanggihan-kecanggihan teknologi. Hal yang sama dengan konsep Piotr Sztompka (2007: 3), kehidupan sosial dan kultural sehari-hari masyarakat akhir-akhir ini memperlihatkan berbagai pengaruh yang amat kuat dari apa yang disebut sebagai pola-pola kehidupan masyarakat global (global society) 
dan budaya global (global culture), sehingga mengakibatkan perubahan mencakup sistem sosial.

Eksistensi budaya masyarakat lokal mampu menjaga dan mengayomi berkesenian, seperti hal budaya etnis Hindu di Bali. Dari kajian beberapa sumber artefak, sistem nilai menunjukan perkembangan kriya tradisional, seperti telah diuraikan di atas tidak terlepas dari peran agama, adat dan budaya sebagai proteksi serta pengayomnya. Celah dimaksudkan tersebut mendorong ekspresi budaya tradisional (EBT) yang mencerminkan nilai-nilai kebaharuan dan keoriginalan sebagai syarat dari kepemilikan Hak Kekayaan Intelektual (HKI) dalam bidang Hak Cipta.

\section{HAK KEKAYAAN INTELEKTUAL(HKI)}

Hak atas Kekayaan Intelektual (HaKI), selanjutnya disebut HKI, sejalan dengan keputusan menteri Hukum dan Perundang-Undangan RI Nomor M.03.PR.07.10 Tahun 2000 dan Persetujuan Menteri Aparatur Negara No.24/M/PAN/1/2000 adalah hak atas kepemilikan kebendaan yang berwujud dan karya-karya yang timbul atau lahir karena kemampuan intelektualitas manusia (Simorangkir JCT, 2008: 11). HKI sebagai perwujudan budaya global yang mengakui dan memberi perlindungan hukum pada setiap hasil karya intelektua manusia yang diciptakan atas dasar rasio dan nalar, yang memiliki nilai original/ kebaharuan (Saidin 2004: 9). HKI terus berkembang mengikuti perkembangan ilmu pengetahuan dan teknologi dan mendapatkan pengakuan secara nasiona maupun internasional. HKI dapat dikatagorikan menjadi dua, yaitu (1) hak cipta (copy rights) dan (2) hak milik perindustrian (industrial property rights) yang diklasifikasikan menjadi paten, rancang bangun, desain industri, merk dagang, nama dagang (Saidin, 1995: 14)

Pengembangan HKI banyak memberikan peluang kepada kemampuan seseorang atau beberapa orang, secara bersama-sama atas inspirasinya melahirkan suatu ciptaan melalui imajinasi pikiran, kecekatan, keterampilan atau keahlian yang dituangkan ke dalam bentuk yang khas dan bersifat pribadi. Walaupun terkadang untuk menuangkannya seseorang tidak mempunyai keberanian atau ragu orang lain mengetahui tentang keaslian karya ciptaannya. Akan tetapi, tidak demikian ketika HKI telah menjadi bagian dan menjadi milik orang lain, tanpa kesulitan mengakui sebagai miliknya dan baru muncul persoalan gugatmenggugat.

Hak kekayaan intelektual (HKI) adalah hak atas kepemilikan kebendaan tidak berwujud dari daya cipta, rasa karsa. Manusia normal memiliki daya pikir kemampuan intelektual atau kemampuan otak, meskipun kemampuan intelektua tersebut tidak sama dibawa sejak lahir tergantung kemampuan intelektual yang dapat dibentuk melalui pendidikan dan latihan. Ada kemampuan intelektual bidang tertentu diarahkan pada suatu kegiatan untuk menghasilkan dan memperoleh sesuatu karya atau temuan (invensi), misalnya ilmu pengetahuan, teknologi, seni dan sastra termasuk dalam jenis Hak Cipta.

Hak Cipta adalah hak alami yang bersifat absolut dan dilindungi haknya selama si pencipta hidup dan beberapa tahun setelah si pencipta meninggal dunia. Dapat dipertahankan terhadap siapa pun, serta menuntut terhadap pelanggaran yang dilakukan oleh siapa pun. Karena sifatnya yang abstrak (incorporeal property), yang merupakan penguasaan atas hasil kemampuan imajinasi, gagasan dan pikiran, yang apabila telah habis masa perlindungannya akan menjadi milik umum (domaind public).

Menurut Stanley Rubenstain sekitar tahun 1740, pertama kali orang mempergunakan istilah Hak Cipta (copyright) untuk menggambarkan konsep guna melindungi penerbit dari tindakan penggandaan buku oleh pihak- pihak yang tidak mempunyai kepentingan untuk menerbitkannya. Hal ini sesuai dengan jaminan atas investasi segi ekonomi yang diberikan penerbit kepada pencipta terhadap pembiayaan pencetakan suatu karya. Kenyataan pemberian perlindungan yang tidak berimbang ini menyebabkan terjadinya pergeseran perubahan perlindungan hak cipta yang makin luas, mencakup bidang drama, musik dan pekerjaan artistik (artistic work, begitu juga terhadap karya cipta sinematografi, fotografi, rekaman suara, dan penyiaran. Dan menurut konsep droit d'aueteur, hak pengarang memiliki hak alamiah (natural right) atas apa yang diciptakannya meliputi hak moral dan hak ekonomi.

Sedangkan perlindungan Hak Cipta di Indonesia sebenarnya sudah ada sejak zaman Penjajahan Belanda yaitu Auteurswet 1912 yang terus berlaku setelah Proklamasi Kemerdekaan Republik Indonesia berdasarkan Peraturan Peralihan Undang- Undang dasar Republik Indonesia tahun 1945, sampai diundangkannya Undang-Undang Republik Indonesia Nomor 6 Tahun 1982 tentang Hak Cipta. Lahirnya Undang-Undang Republik Indonesia Nomor 19 Tahun 2002 tentang Hak Cipta banyak mengalami perubahan sesuai kehendak zaman serta kondisi masyarakat. Masyarakat memerlukan keberadaan Undang-Undang yang dapat memberikan perlindungan hukum bagi Pencipta atas karya-karya yang diciptakannya. Setelah Indonesia kembali bergabung menjadi anggota Berne Convention (Konvensi Internasional dibidang Hak Cipta), maka para Pencipta/ Pemegang Hak Cipta mempunyai kesempatan untuk dapat melindungi hak-hak atas imajinasi, gagasan dan pikiran. Tidak memberi kesempatan pada orang- orang yang hanya mencari keuntungan saja tanpa harus memikirkan kesulitan proses penciptaan si Pencipta.

Walaupun masih dirasakan adanya kesulitan untuk mendapatkan perlindungan hukum pada Kriya tradisional telah masuk dalam "foklor" yang diatur dalam undang-undang. Melihat keunikan karakter masing- masing daerah 
yang tidak dimiliki oleh daerah- daerah lain di seluruh wilayah kebudayaan Indonesia sebagai bagian dari traditional knowledge, berupa kesenian rakyat, maupun teknologi-teknologi tradisional yang tidak diketahui asal muasalnya (anonim) secara turun temurun hidup di tengah- tengah tatanan kehidupan masyarakat daerah setempat. Kalau saja hal ini diakui sebagai sistem kepemilikan yang bersifat individu (private property) akan menyebabkan kesulitan bag perlindungan terhadap karya karya tradisional yang jumlahnya belum teridentifikasi dan terinventarisasi.

Akhirnya yang menjadi tumpuan harapan adalah merujuk pada ketentuan Undang- Undang Republik Indonesia Nomor 19 Tahun 2002 tentang Hak Cipta, pasal 10 Ayat (1) dan (2); dimana Negara memegang Hak Cipta atas karya- karya peninggalan pra- sejarah, sejarah, dan benda cagar budaya nasional lainnya. Hasi kebudayaan rakyat yang menjadi milik bersama, folklor seperti cerita hikayat, dongeng, legenda, babad, lagu, kerajinan tangan, koreografi, tarian, kaligrafi, dan karya seni lainnya, yang akan diatur dalam peraturan pelaksana Peraturan Pemerintah (Undang-Undang HAKI, 2003; 1). Hal ini sebagai upaya perlindungan hukum terhadap pihak asing yang berusaha secara berbagai cara memanfaatkan karya budaya atau pengetahuan tradisional. Dengan Peraturan Pemerintah tersebu kearifan budaya lokal dapat dilestarikan dan menghindari kerugian Negara Indonesia atau masyarakat tradisional setempat dari jarahan asing.

\section{PERSPEKTIF HAK KEKAYAAN INTELEKTUAL(HKI)}

Permasalahan HKI akan terus berkembang mengikuti perkembangan ilmu pengetahuan dan teknologi, seiring perubahan aspek penghargaan atau pengakuan secara nasional maupun internasional. Terbukti permasalahan HKI sudah semakin majemuk dan kompleks, bahkan sampai melibatkan kepentingan-kepentingan perlindungan yang sifatnya tidak lagi timbal- balik, tetapi sudah bersifat antar negara. Hal ini sebagai suatu tantangan kesiapan Indonesia menghadapi AFTA (ASEAN Free Trade Area) merupakan wujud kesepakatan dari negara-negara ASEAN untuk membentuk suatu kawasan perdagangan bebas dalam rangka meningkatkan daya saing ekonomi di kawasan regional, untuk meningkatkan kesejahteraan masyarakat negara-negara ASEAN.

Sebagian besar produk industri, termasuk kriya tradisional, dipasarkan melalui perdagangan bebas dan dikukuhkan dengan HKI. Tanpa disadar sebagaian besar pelaku dunia usaha menganggap HKI tidak memiliki peran dalam menentukan dan memenangkan pasar di era ekonomi Global. Jenis-jenis HKI yang di atur dalam Kitab Undang-Undang HaKI adalah sebagai berikut.
1. Dalam Undang-undang Republik Indonesia Nomor 14 Tahun 2001 tentang paten, terdapat tindak pidana paten sebagai berikut:

a. Sengaja dan tanpa hak membuat, menggunakan, menjual, mengimpor, menyewakan, menyerahkan, atau menyediakan untuk dijual atau disewakan atau diserahkan produk yang diberi paten (Pasal 130 jo Pasal 16 Ayat (1) huruf a)

b. Dalam hal paten proses sengaja dan tanpa hak menggunakan proses produksi yang diberi paten untuk membuat barang ( Pasal 130 jo Pasal 16 Ayat (1) huruf b)

c. Dalam hal paten produk sengaja dan tanpa hak membuat, menggunakan, menjual, mengimpor, menyewakan, menyerahkan atau menyediakan produk yang diberi paten Sederhana (Pasal 131 jo Pasal 16 Ayat (1) huruf a)

d. Dalam hal paten proses, sengaja dan tanpa hak menggunakan proses produksi yang diberi paten sederhana untuk membuat barang (Pasal 131 jo Pasal 16 Ayat (1) huruf b)

e. Sebagai kuasa sengaja tidak menjaga kerahasiaan invensi dan seluruh dokumen permohonan (Pasal 132 jo Pasal 25 Ayat (3)

f. Dilakukan oleh pegawai Direktorat Jenderal sengaja mengajukan permohonan, memperoleh hak, atau memegang hak yang berkaitan dengan paten (Pasal 132 jo Pasal 40 )

g. Dilakukan oleh aparat Direktorat Jenderal sengaja tidak menjaga kerahasiaan invensi dan seluruh dokumen permohonan (Pasal 132 jo pasal 4)

2. Dalam Undang-Undang Republik Indonesia Nomor 15 Tahun 2001 tentang Merek, terdapat tindak Pidana Hak Merek sebagai berikut:

a. Mempergunakan merek yang sama keseluruhannya dengan Merek terdaftar milik pihak lain untuk barang dan/atau jasa sejenis (Pasal 90 )

b. Mempergunakan Merek yang sama pada pokoknya dengan Merek terdaftar milik pihak lain (Pasal 91)

c. Mempergunakan tanda yang sama pada keseluruhan dengan indikasigeografis milik pihak lain (Pasal 92 Ayat (1)

d. Mempergunakan tanda yang sama pada pokoknya dengan indikasi geografis milik pihak lain (Pasal 92 Ayat (2)

e. Mencantumkan asal sebenarnya pad barang hasil pelanggaran atau pencantuman kata yang menunjukan barang merupakan tiruan dari barang terdaftar (Pasal 92 Ayat (3)

f. Mempergunakan tanda yang dilindungi berdasarkan indikasi pada barang atau jasa (Pasal 93) 
g. Memperdagangkan barang dan/atau jasa hasil pelanggaran Pasal 90, 91, 92 atau 93 (Pasal 94 jo Pasal 90 jo 91 jo 92 dan pasal 93) Apabila dilihat dari sudut obyeknya maka tindak pidana pada huruf $g$ terdiri atas empat macam.

3. Dalam Undang-Undang Republik Indonesia Nomor 19 Tahun 2002 tentang Hak Cipta, terdapat tindak pidana Hak Cipta sebagai berikut.

a. Tanpa persetujuan pelaku membuat, memperbanyak, atau menyiarkan rekaman suara dan/atau gambar pertunjukan pelaku (Pasal 72 Ayat (1) jo Pasal 49 Ayat (1)

b. Tanpa persetujuan produser rekaman memperbanyak dan/ atau menyewakan karya rekaman suara atau rekaman bunyi (Pasal 72 Ayat (1) jo Pasal 49 Ayat (2)

c. Dengan sengaja menyiarkan, memamerkan, mengedarkan atau menjual ciptaan atau barang hasil pelanggaran hak cipta atau hak yang terkait (Pasal 72 Ayat (2)

d. Dengan sengaja dan tanpa hak memperbanyak penggunaan untuk kepentingan komersial program komputer (Pasal 72 Ayat (3)

e. Dengan sengaja mengumumkan ciptaan yang bertentangan dengan kebijaksanaan pemerintah di bidang agama, pertahanan dan keamanan negara, kesusilaan serta ketertiban umum (pasal 72 Ayat (4) jo Pasal 17)

f. Dengan sengaja memperbanyak atau mengumumkan potret tanpa izin pemiliknya atau ahli warisnya (Pasal 72 Ayat (5) jo Pasal 19)

g. Dengan sengaja mengumumkan potret orang yang dibuat tanpa persetujuan orang yang dipotret apabila bertentangan dengan kepentingan yang wajar dari orang yang dipotret (Pasal 72 Ayat (5) jo Pasal 20)

h. Dengan sengaja membuat, memperbanyak dan/ atau menyiarkan ulang karya siaran melalui transmisi (Pasal 72 Ayat (5) jo Pasal 49 Ayat (3)

i. Dengan sengaja memegang dan tanpa hak hak cipta, tidak mencantumkan nama pencipta dan mengubah ciptaan (Pasal 72 Ayat (6) jo Pasal 24)

y. Dengan sengaja dan tanpa hak meniadakan nama pencipta, mengganti atau mengubah judul atau isi ciptaan (Pasal 72 Ayat (6) jo Pasal 55)

k. Dengan sengaja dan tanpa hak meniadakan atau mengubah informasi elektronik tentang informasi manajemen hak pencipta (Pasal 72 Ayat (7) jo Pasal 25)

1. Dengan sengaja dan tanpa hak merusak, meniadakan atau dibuat tidak berfungsi sarana kontrol teknologi sebagai pengaman hak pencipta (Pasal 72 Ayat (8) jo Pasal 27)

m. Dengan sengaja tidak memenuhi kewajiban perizinan dan persyaratan produksi yang ditetapkan (Pasal 72 Ayat (9) jo Pasal 28)
4. Dalam Undang-Undang Republik Indonesia Nomor 29 Tahun 2000 tentang Perlindungan Varietas Tanaman, terdapat tindak pidana Varietas Tanaman sebagai berikut.

a. Dengan sengaja memproduksi atau memperbanyak benih, mengiklankan, menawarkan, dan lain- lain varietas tanaman tanpa persetujuan pemegang hak PVT (Pasal 71 jo Pasal 6 Ayat (3)

b. Konsultan PVT yang dengan sengaja tidak merahasiakan varietas tanaman dan dokumen permohonan hak PVT (Pasal 72 jo Pasal 13 Ayat (1)

c. Pegawai kantor PVT dengan sengaja tidak merahasiakan varietas tanaman dan dokumen permohonan hak PVT (Pasal 72 jo Pasal 23)

d. Dengan sengaja untuk tujuan komersial menggunakan hasil panen dari varietas tanaman yang dilindungi (Pasal 73 jo pasal 10 Ayat (1)

e. Pemeriksa PVT atau Pejabat yang terkait dengan pemeriksaan substantif dengan sengaja tidak menjaga kerahasiaan varietas yang diperiksanya (Pasal 74 jo Pasal 30 Ayat (3)

6. Dalam Undang-Undang Republik Indonesia Nomor 30 Tahun 2000 tentang Rahasia Dagang, terdapat tindak pidana Rahasia Dagang sebagai berikut:

a. Dengan sengaja dan tanpa hak menggunakan rahasia dagang pihak lain (Pasal 17 Ayat (1)

b. Dengan sengaja mengungkapkan rahasia dagang, mengingkari kesepakatan, atau mengingkari kewajiban menjaga rahasia dagang ( pasal 17 Ayat (1) jo Pasal 13)

c. Dengan sengaja memperoleh atau menguasai rahasia dagang dengan cara yang bertentangan dengan peraturan perundang-undangan yang berlaku (Pasal 17 Ayat (1) jo Pasal 14)

7. Dalam Undang- Undang Republik Indonesia Nomor 31 Tahun 2000 tentang Desain Industri, terdapat tindak pidana desain Industri sebagai berikut.

a. Dengan sengaja dan tanpa hak membuat, memakai, menjual, mengimpor, mengekspor dan/ atau memgedarkan barang yang diberi hak desain industri (Pasal54 Ayat (1) jo Pasal 9)

b. Dengan sengaja tidak mencantumkan nama pendesaian hak desain industri dalam sertifikat desain industri, daftar umum desain industri, dan berita resmi desain industri (Pasal 54 Ayat (2) jo Pasal 8)

c. Dengan sengaja melanggar kewajiban menjaga kerahasiaan permohonan sampai dengan diumumkannya permohonan hak desain industri (Pasal 54 Ayat (2) jo pasal 23) 
d. Dalam hal pengalihan hak desain industri dengan sengaja tidak lagi mencantumkan nama dan identitas pendesain desain industri, maupun dalam daftar umum desain industri (Pasal 54 ayat (2) jo Pasal 32)

8. Dalam Undang-Undang Republik Indonesia Nomor 32 Tahun 2000 tentang Desain Tata Letak Sirkuit Terpadu (DTLST), terdapat tindak pidana DTLST sebagai berikut.

a. Dengan sengaja dan tanpa hak membuat, memakai, menjual, mengimpor mengekspor, dan/ atau mengedarkan barang yang didalamnya terdapa seluruh atau sebagian desain yang telah diberi hak DTLST (Pasal 42 Ayat (1) jo Pasal 8 Ayat (1)

b. Dengan sengaja tidak mencantumkan nama pendesaian dalam sertifikat DTLST, daftar umum DTLST, dan berita resmi DTLST (Pasal 42 Ayat (2) jo Pasal 7)

c. Pegawai Direktorat Jenderal atau orang yang karena tugasnya bekerja untuk dan/ atau atas nama direktorat jenderal sengaj tidak menjaga kerahasiaan permohonan (Pasal 42 Ayat (2) jo Pasal 19)

d. Dalam hal pengalihan hak DTLST dengan sengaja tidak lagi mencantumkan nama dan identitas pendesain DTLST dalam sertifika DTLST, berita resmi DTLST, maupun dalam daftar umum DTLST (Pasal 42 Ayat (2) jo Pasal 24). Peraturan Pemerintah Nomor 51 Tahun 2007 memberikan batasan tentang pengertian "indikasi geografis" sebaga suatu tanda yang menunjukan daerah asal suatu barang, yang karena faktor lingkungan geografis termasuk faktor alam, manusia, kombinasi kedua faktor tersebut, memberikan ciri dan kualitas tertentu pada barang yang dihasilkan. Juga merupakan nama tempat atau daerah maupun tand tertentu lainnya yang menunjukan asal tempat dihasilkannya barang yang dilindungi oleh "indikasi Geografis."

\section{KRIYATRADISIONAL DALAM HAK CIPTA}

Pemahaman tentang traditional knowledge yang terdapat dalam Pasal 10 Ayat (1) dan (2) Undang-undang Republik Indonesia Nomor 19 Tahun 2002 tentang Hak Cipta merupakan masalah hukum baru yang berkembang, baik ditingkat nasional maupun internasional. Hal ini disebabkan belum terpenuh instrumen hukum domestik yang memberikan perlindungan secara optimal pada kriya tradisional dan sering dimanfaatkan oleh pihak-pihak yang tidak bertanggung jawab, karena tidak dapat dipisahkan dari masyarakat pemegangnya sebagai bentuk way of life yang lahir dari semangat untuk bertahan (survive).

Oleh karena pemahaman tentang traditional knowledge, merupakan pengetahuan tradisional tentang inovasi dan praktik dari masyarakat loka dikembangkan melalui pengalaman negara-negara dan diadaptasi ke budaya lokal dari generasi ke generasi, lalu menjadi milik kolektif. Untuk perlindungan yang mempertahankan traditional knowledge melalui hukum tradisional (exsiting legal mechanisms), berupa kontrak pembatasan akses (acces restriction), yang sifatnya tidak mengikat, dengan mengadopsi ketentuan internasional, pemerintah dan sektor swasta, organisasi kemasyarakatan profesional, dalam bentuk kompilasi penemuan, pendaftaran dan data base tentang pengetahuan tradisional.

Walaupun perlindungan mengenai "foklor" termasuk kriya tradisional masih dirasakan sulit ditentukan, karena kesulitan dalam membuktikan keasliannya, maka banyak orang asing mencuri kesempatan untuk mengeksploitasi karya-karya tradisional, seperti yang terjadi pada ragam hiasan Kalimantan, Ponorogo, Bali (Lodra, 2011). Tanpa izin pencipta karya tradisional, ataupun yang melalui negara karya tradisional tersebut diambil, dirampas dilindungi dengan Hak Cipta dan menjadi milik idividu. Kenyataan memprihatinkan mengingat bangsa ini sangat potensial dalam hal kekayaan traditional knowledge. Kondisi semacam ini akan semakin terpuruk dan tidak akan bisa dinikmati oleh generasi berikutnya, jika dibiarkan tanpa ada proteksi dan tidak ada kebanggaan pada nilai-nilai tradisi budaya yang telah tumbuh dan hidup secara turun temurun hidup di masyarakat.

\section{INDIKASI PELANGGARAN HAK KEKAYAAN INTELEKTUAL}

Pelanggaran terhadap Hak Kekayaan Intelektual (HKI) memiliki ruang lingkup yang sangat luas dan kompleks, meliputi pemalsuan, pembajakan, penyadapan, dan pembocoran informasi rahasia, menawarkan, serta memperdagangkan. Di dalam mengidentifikasi pelanggaran ketentuan undangundang HKI, lebih terfokus pada pelanggaran Hak Cipta, sering menjadi polemik di masyarakat.

Menurut Pasal 1 Angka 3 UU RI No.19 Tahun 2002, yang dimaksudkan dengan ciptaan adalah hasil setiap karya pencipta yang menunjukan keasliannya dalam lapangan ilmu pengetahuan, seni atau sastra. Hal ini mencakup dalam Pasal 12

Buku, program komputer, pamflet, perwajahan (lay out) karya tulis yang diterbitkan dan semua hasil karya tulis. Yang dimaksud dengan perwajahan karya tulis adalah karya cipta yang lazim dikenal dengan typhographical arrangement, yaitu aspek seni dalam susunan dan bentuk penulisan karya tulis. Hal ini mencakup antara lain format, hiasan, warna, dan susunan atau tata letak huruf indah yang secara keseluruhan menampilkan wujud yang khas. Berlaku selama hidup pencipta, hingga 50 (lima puluh) tahun setelah meninggal dunia penciptanya. 
b. Ceramah, kuliah, pidato, dan ciptaan lain yang sejenis dengan itu. Yang dimaksud dengan ciptaan lain yang sejenis adalah ciptaan-ciptaan yang belum disebutkan, tetapi dapat disamakan dengan ciptaan-ciptaan, seperti ceramah, kuliah, dan pidato.

c. Alat peraga yang dibuat untuk kepentingan pendidikan dan ilmu pengetahuan; adalah ciptaan yang bebentuk dua ataupun tiga dimensi yang berkaitan dengan geografi, topografi, arsitektur, biologi, atau ilmu pengetahuan lain.

d. Lagu atau musik dengan atau tanpa teks, yang diartikan sebagai karya yang bersifat utuh, sekalipun terdiri atas unsur lagu atau melodi, syair atau lirik, dan aransemennya termasuk notasi.

e. Drama atau drama musikal, tari, koreografi, pewayangan dan pantomim

f. Seni rupa dalam segala bentuk, seperti seni lukis, gambar, seni ukir, seni kaligrafi, seni pahat, seni patung, kolase dan seni terapan. Yang dimaksud gambar, antara lain motif, diagram, sketsa, logo, dan bentuk huruf indah dan gambar tersebut dibuat bukan untuk tujuan desain industri.

g. Arsitektur, antara lain meliputi seni gambar bangunan, seni gambar miniatur, dan seni gambar maket bangunan.

h. Peta. Suatu gambaran dan unsur-unsur alam dan/atau buatan manusia yang berada di atas ataupun di bawah permukaan bumi yang digambarkan pada suatu biang datar dengan skala tertentu.

i. Seni batik, yang dibuat secara konvensional dilindungi dalam undang-undang. Ini sebagai bentuk ciptaan tersendiri, karena memiliki nilai seni, baik pada ciptaan motif atau gambar maupun komposisi warnanya.

j. Fotografi

k. Sinematografi. Karya ini merupakan media komunikasi massa gambar gerak (moving images), antara lain film dokumenter, film skenario, dan film kartun. Karya tersebut dibuat dalam pita seluloid, pita video, piringan video, cakram optik dan/atau media lain yang memungkinkan untuk dipertunjukan di bioskop, di layar lebar atau ditayangkan di televisi atau di media lainnya.

1. Terjemahan, tafsir, saduran, bunga rampai, database, dan karya lain dari hasil pengalihwujudan. Yang dimaksud bunga rampai adalah ciptaan dalam bentuk buku yang berisi kumpulan karya tulis pilihan, himpunan lagu-lagu pilihan yang direkam dalam satu kaset, cakram optik atau media lain, serta komposisi berbagai karya tari pilihan. Yang dimaksud dengan database adalah kompilasi data dalam bentuk apapun yang dapat dibaca oleh mesin (komputer) atau dalam bentuk lain, yang karena alasan pemilihan atau pengaturan atas isi data itu merupakan kreasi intelektual. Yang dimaksud dengan pengalihwujudan adalah pengubahan bentuk, misalnya dari bentuk patung menjadi lukisan, cerita roman menjadi drama, drama menjadi sandiwara radio dan novel menjadi film. Keseluruhannya berlaku selama hidup pencipta, hingga 50 (lima puluh) tahun setelah meninggal dunia penciptanya.

Yang berhubungan dengan Hak Moral, suatu ciptaan tidak boleh diubah walaupun hak ciptanya telah diserahkan kepada pihak lain, kecuali dengan persetujuan pencipta atau dengan persetujuan ahli warisnya dalam hal pencipta telah meninggal dunia (Pasal 24 Ayat (2). Sedangkan bentuk pelanggaran terhadap Hak Cipta pada dasarnya berkisar pada 2 (dua) hal pokok. Pertama, dengan sengaja dan tanpa hak mengumumkan, memperbanyak atau memberi izin untuk itu, sepanjang tidak bertentangan dengan kebijaksanaan pemerintah di bidang pertahanan dan keamanan negara, kesusilaan serta ketertiban umum. Kedua, dengan sengaja memamerkan, mengedarkan atau menjual kepada umum sesuatu ciptaan atau barang hasil pelanggaran hak Cipta. Pelanggaran Hak Cipta yang dilakukan dengan sengaja dan tanpa hak dapat dipidana penjara paling lama 7 (tujuh) tahun dan/ atau denda paling banyak Rp.5.000.000.000,00 (lima miliyar rupiah) di atur dalam Pasal 72 Ayat (1) ).

\section{PENUTUP}

Agar perlindungan hukum kekayaan intelektual (KI) terhadap pengetahuan traditional knowledge akan berakibat pada peningkatan ekonomi yang mampu bersaing dalam pasar global, sekaligus dapat memperoleh atau memiliki kembali aset-aset yang telah diklaim atau diakui sebagai hak milik negara atau bangsa lain tidak akan terulang lagi. Oleh karena itu, perlu adanya pembudayaan HKI di masyarakat.

Perlindungan di bidang HKI akan efektif apabila berbagai ketentuan perundang-undangan di bidang Hak Cipta dilaksanakan dengan tertib oleh masyarakat serta ditegakkan secara konsisten oleh Penegak Hukum, Penyidik PPNS Hak Kekayaan Intelektual, Penuntut Umum, dan Lembaga Peradilan Tata Niaga dan lembaga lain yang terkait.

Catatan Daftar Pustaka: Tulisan cetak merah menunjukkan kalau daftar tersebut tidak digunakan dalam pembahasan. Rekomendasi ke tim redaksi dicoret saja. Terima kasih.

\section{DAFTAR PUSTAKA}

Asian Law Group Pty. Ltd, Indonesia Australia Specialised Training Project Phase II, Intellectual Property Rights ( Elementary)Indonesia, AusAID IASTP.

Adolf, Huala, 2008, Hukum Penyelesaian Sengketa Internasional, Jakarta, Sinar Grafika. 
Bagus, I Gusti Ngurah,1997, Masalah Budaya dan Pariwisata dalam Pembangunan, Denpasar, Kajian Budaya Udayana

Budi Agus Riswandi, M. Syamsudin, 2004, Hak Kekayaan Intelektual ,Jakarta, PT. Raja Grafindo Persada.

Chazawi, Adami, 2007, Tindak pidana Hak atas Kekayaan Intelektual, Malang, Bayumedia Publishing.

Djaja S. Meliala, 2007, Perkembangan Hukum Perdatatentang Benda dan Hukum Perikatan, Bandung, CV. Nuansa Aulia.

Emirzon, Joni, 2001, Alternatif Penyelesaian Sengketa di luar Pengadilan (Negoisasi, Mediasi, Konsiliasi dan Arbitrase ), Jakarta, PT. Gramedia Pustaka Utama.

Erma Wahyuni, T. Saiful Bahri, Hessel Nogi S Tangkilisan, 2007, Kebijakan dan Manajemen Hukum Merek, Yogyakarta, Yayasan Pembaruan Administrasi Publik Indonesia (YPAPI).

Gautama, Sudargo, Rizawanto Winata, 1993, Hukum Merek Indonesia, Bandung, PT. Citra Adtya Bakti.

Gautama, Sudargo, 1995, Segi- Segi Hukum Hak Milik Intelektual, Jakarta, PT. Eresco.

Kitab Undang- Undang Hak Atas Kekayaan Intelektual HaKI, Permata Press.

Lodra. 2012. Kriya Tradisional dalam Cengkraman Kapitalis. Sari Kayangan: Indonesia.

2013. Media Religi Dalam Pusaran Global. Bintang Surabaya: Surabaya

Muhammad Djumhana, Djubaedillah, 2003, Hak Milik Intelektual, Sejarah, Teori dan Prakteknya di Indonesi, Bandung, PT. Citra Aditya Bakti.

Tjahyo Harry Wilopo, 2007, Jurus Jitu Membangun Merek untuk UKM, Yogyakarta, Medpress.

Faisal Salam, Moch, Penyelesaian sengketa Bisnis secara Nasional dan Internasional, Mandar Maju, Jakarta, 2007

Saidin, H. OK. 2004. Aspek Hukum Hak Kekayaan Intelektual. Grafindo Persada: Jakarta 